\title{
McCarthyism and Its Influence on the Reporting Career of Edgar Snow
}

\author{
Chen Yong \\ School of Foreign Languages, East China Institute of Technology \\ Nanchang, Jiangxi Province, People's Republic of China \\ Yongchen@ecit.cn
}

\begin{abstract}
Edgar Snow's Red Star over China, together with other reports on red China and Chinese revolution, plus his red China experiences, has brought him much trouble during the McCarthy era. The unfair treatment or even persecution done to him comes from four major aspects: FBI, Congress, right-wing media and anti-communist ally, which form the chain against Edgar Snow, with FBI playing the leading role. It reveals for the first time the whole mechanism that functions in the unfair treatment of Snow on the basis of his works and Edgar Snow Papers.
\end{abstract}

Keywords-Edgar Snow; McCarthyism; reporting career

\section{INTRODUCTION}

Edgar Snow, the well-known American journalist, is an old friend of Chinese people. He is famous for his masterpiece, Red Star over China, which for the first time introduces the true state of Chinese Communist Part (CCP) and her Red Army to the whole world. Of his eleven books, nine are on China. Therefore, he is usually regarded as real China interpreter. However, his deep understanding of China also involves him in China affairs. In February, 1941, Snow was forced to leave China by KMT Government because he uncovered the truth of South Anhui Incident and made public the lie of KMT, who was irritated by Snow's report.

After returning to his home country, Snow was faced with persecution of McCarthyism. Academic research on this theme is rare except for the occasional touch of John Maxwell Hamilton in Edgar Snow: a Biography and articles in memory of Snow. This article explores the unfair treatment done by the chain of FBI-Congress-right wing media-anticommunist ally on the basis of Snow's works, Edgar Snow Papers, and the social background in McCarthy era.

\section{MEET OF MCCARTHYISM AND JOURNALIST SNOW}

Snow's reporting career in America in post-war era can be divided into two phases: the first phase lasted roughly from 1941 to 1951 , when Snow was working for Saturday Evening Post as both a journalist and associate editor, and published plenty of works on China, like "Must China Go Red?" "Will China Become a Soviet Satellite?" The Battle for Asia, People On Our Side, Pattern of Soviet Power, Stalin Must Have Peace, and so on. In February, 1951, Snow resigned from the Post for disagreeing with McCarthyism, which became, to certain degree, the turning point in his reporting career. The second phase lasted roughly from 1951 to 1959 , when his works were scrutinized and his freedom of speech was restricted. After leaving the Post, Snow published only a few articles on The Nation and two books: Journey to the Beginning and Random Notes on Red China, which was mainly for academic research. During this period of time, his application for visiting red China was also rejected by State Department. Snow has already been targeted by McCarthyism and anti-communist forces which hated red China much.

McCarthyism is the epitome of anti-communist forces during the early cold war era. Senator Joseph McCarthy claimed to have in his hand fifty-seven cases of individuals who would appear to be either card carrying members or certainly loyal to the Communist Party but who nevertheless were still helping to shape US foreign policy in a speech to a Republican Women's Club in Wheeling, West Virginia on February 1950[1]. The accusation caused a big sensation in the United States. Within weeks of entering the headlines, the senator also entered the American language. In the March 29, 1950, edition of the Washington Post, editorial cartoonist Herbert Block first used the senator's surname as a term of abuse, the emblem of a smear, when he scrawled "McCarthyism" on a tar pot [2]. "It is the corruption of truth, the abandonment of our historical devotion to fair play. It is the abandonment of the due process of law. It is the use of the Big Lie and the unfounded accusation against any citizen in the name of Americanism and security" [2], as former President Harry S. Truman voiced his definition of McCarthyism, which reached its peak from 1950 to 1954 , overlapping the climax of anti-communist crusade in the early 1950s. Federal agencies like FBI (with director J. Edgar Hoover), Dies Committee and House Un-American Activities Committee (HUAC) played key roles in the anti-communist crusade, with the help of private interest groups, patriotic organizations like American Legion, VFW, and activists without portfolio, who adopt various means, like unpublicized firing, blacklisting, FBI investigation, speakers' bans, Congress hearing, passport denials, public opprobrium, a hassle of a lifetime, etc, to persecute the so-called communists or their followers and sympathizers, who were considered to be dangerous and treated unfairly. 


\section{CHAIN OF \\ FBI-CONGRESS-MEDIA-ANTICOMMUNIST ALLY}

\section{A. FBI's Role}

FBI plays the leading role in the unfair treatment of Edgar Snow. From late 1940s to early 1950s, while politicians were discussing heatedly who should be responsible for the "loss" of China, FBI had already started its investigation of Edgar Snow on his Red experiences. As early as in 1946, FBI had drafted a 23-page background report on Snow, of which six pages were quoted from an article on an American Communist Party publication, and made a deliberate misinterpretation out of its context [3]. FBI also collected and analyzed articles published by Snow, and then drew a conclusion that Snow was a sympathizer of CCP. From "Must China Go Red?" FBI believed that Snow was standing side by side with communist government in Yenan and disagreed with US government politically [4]; From Red Star over China, FBI held that there was too much "Red" in it, that Snow's purpose of writing it was doubtful, and that Snow was pro-communist [5]. FBI even recorded that an anonymous source reported that Snow agreed "to accept communist discipline" while writing Red Star and the book had been written to "satisfy party instructions" [6]. Though there was no sound evidence to prove that Snow was a communist, the investigations themselves had caused a sensational effect.

\section{B. Congress's Role}

Congress was the center in the anticommunist crusade. FBI leaked deliberately and selectively information of people investigated to Senator McCarthy, HUAC, and other congressional sub-committees. There were about 555 pages of Snow file, of which 484 pages have been leaked to HUAC deliberately [7]. McCarran Committee was also extremely interested in people like Snow, and in its records of hearings during the 1950s to 1960 s, Snow was mentioned over 120 times. Snow, therefore, was sorted out as pro-communist and put in the blacklist of "complicated communists and liberals" [8]. Summoned to Congressional hearings and appearing on headlines time and again, Snow was labeled as the so-called "red, dangerous radicals". Media added fuel to the fire in the anticommunist furor. The right wing attacked Snow as communist propagandist and agent. Alfred Kohlberg, the staunch anticommunist, head of the so-called "China Lobby", close ally of Senator McCarthy, once published an article on Plain Talk (which is the mouthpiece of those extreme conservatives who support KMT) attacking Snow's stand, and its copies were even distributed all over the country among celebrities who were further advised to put pressure on Saturday Evening Post to get rid of Snow. When Snow suggested on the Post that the US establish direct diplomatic relationship with PRC, his stand was condemned severely by Patrick J. Hurley, former US ambassador to China, who wrote to Post protesting that Snow was broadcasting rumors in pro-communist articles. Post itself was also criticized by McCarthy, which was the direct reason why Snow should leave his position at the Post. When The Nation published Snow's article, it was even driven out of school libraries in New York City and Newark by McCarthy and his followers [1].

\section{Role played by private anticommunist ally}

The unfair treatment done to Edgar Snow came also from a private anticommunist ally consisting of extreme conservatives within Republican Party, right wing, "China Lobby" who supported Chiang Kai-shek, with senator McCarthy as their mouthpiece. This was in nature an interest group, with members including businessmen, politicians, Republicans, publishers, etc, of whom the most notorious one was Alfred Kohlberg, Henry Luce the Time magazine publisher, former candy lollipops manufacturer and founding director of the staunch right wing activist John Birch Society (which spent millions of dollars each year in anticommunist propaganda) Robert W. Welch. Jr., who claimed that in the past two decades, the most serious mistake made by the Post was publish Snow's articles which brainwashed Americans, made communist power call the tune among Americans, and sold China to the puppet of Kremlin [9].

This chain hurt Snow a lot. First, Snow could not make his thoughts public freely in America. Of the 25 articles sent to the Post from 1950 to 51, only 3 were published finally. When The Nation magazine accepted Snow's article, it was banned in New York City. Second, Snow's works were scrutinized and banned by the right wing both in Japan by general McArthur when Snow was there from 1945 to 46 [10] and at Easter time of 1953 when McCarthy's staff-Roy M. Cohn and G. David Schine-toured Europe together to investigate the contents of US overseas libraries, with Snow on the list of suspected authors [11], and went to the kind of extremes that reminded many of the book purges in Germany during Hitler's time [12]. Snow rejected these charges and also wrote on New York Times to protest [13]. However, with the headline stories, the public seemed to believe that Snow's books were harmful. Third, Snow's application for permission to visit PRC was denied time and again, and the State Department even ordered that no Americans be allowed to visit PRC, and no books on PRC be published [9].

\section{SNOW's STAND ON RED CHINA ISSUE}

Investigation of Snow originates from the "red" elements in his works, and there are two issues both sides disagree on: first, are Chinese Communists mere "agrarian reformers" or "real communists"? Second, what the relationship between Chinese Communist and the Soviet Union is like? These two issues are related to his masterpiece Red Star over China, in which Snow depicts Chinese Communists and revolution as-a-matter-of-factly. He emphasizes in the book that the Chinese revolution, being of bourgeois-democratic character, has as its primary task the readjustment of the land problem-the realization of agrarian reform, with the realization of socialism or communism their ultimate aim. Snow also states in his interview of Chairman Mao that "we are always social revolutionaries; we are never reformists" [14]. However, in Snow file kept by FBI, critics still believe that Snow has 
cheated Americans by presenting Chinese Communists as little more than a group of modest reformers and hiding deliberately their true nature of communism, even though he has reiterated it in Red Star and other publications as early as the beginning of WWII. In 1945 Snow refuted these charges in "Must China Go Red?" again [15]

As for the relationship between CCP and Soviet Union, Snow has also stated clearly in Red Star: "the rural soviet movement and (Mao') Chinese Red Army began spontaneously, and they did not, in fact, get much applause from Russia till after the Sixth Congress, when the Communist International gave its postnatal sanction" [14]; "the Soviet Union in fact did not extend to the Chinese comrades the promised 'assistance and support of the proletarian dictatorship' in any degree commensurate with the need" [14]; "We are certainly not fighting for an emancipated China in order to turn the country over to Moscow... such a world union could be successful only if every nation had the right to enter or leave the union according to the will of its people, and with its sovereignty intact, and certainly never at the 'command' of Moscow... the myth of 'world domination from Moscow' is an invention of the Fascists and counterrevolutionaries" [14]. In fact, Moscow provided more aid to KMT than to CCP.

Although Snow has made his stand very clearly in Red Star and many other publications, Americans seldom concerned it. Instead, they focused on the "red" elements in his works, attacking Snow as sympathizer, agent, promoter of communism, and even a hidden communist on the basis of personal feelings rather than sound evidence. Deeply influenced by isolationism, Americans had never viewed China realistically. Throughout the twentieth century they had subscribed to highly romanticized notions about the democratic nature of the Chinese government and the special friendship that was said to exist between the US and Republic of China [1], which reached its peak when Mrs. Chiang Kai-shek visited the US from 1942 to 1943 and was admired by both US Congressmen and the public. So "democratic and romantic" was China that many Americans could not accept the image of a corrupted and incompetent government depicted by Snow in Red Star and other publications. Staunch supporters of Chiang Kai-shek refused to admit its military and political defeat and transformed America's China policy into a partisan issue, thus began the hunting of scapegoat. As the first reporter to introduce Red China to the outside world, Snow was inevitably the target for this witch-hunting drama.

\section{V.CONCLUSION}

The era of McCarthyism witnessed the most severe and the widest range of political persecution and was the darkest chapter in American history. Federal and local governments, Congress, media, private sectors, right wing, sensational politicians, interest groups and an unsuspecting public all joined in this anticommunist furor and trampled under foot democracy, freedom and human rights in the name of Americanism and national security. Against such a context, Edgar Snow was persecuted unavoidably by the chain of FBI-congress-right wing media-anticommunist ally.
However, unlike many other Americans, Snow is such a friend as truly concerns the life of common Chinese people and the future of their country.

\section{REFERENCES}

[1] E. Schrecker, The Age of McCarthyism: A Brief History with Documents, New York: Palgrave, 2002, p.75.

[2] [T. Doherty, Cold War, Cool Medium: Television, McCarthyism, and American Culture, New York: Columbia University Press, 2003, pp.14-15

[3] FBI memo to Frederick Tillman, April 15, 1946, Folder One, Edgar Snow Papers; University of Missouri-Kansas City Archives.

[4] FBI memo, Srickland to Ladd, May 25, 1945, Folder One, Edgar Snow Papers; University of Missouri-Kansas City Archives.

[5] FBI Washington Field Office report to the director, May 9, 1950, Folder One, Edgar Snow Papers, University of Missouri-Kansas City Archives.

[6] FBI New York Office report to the director, August 8, 1950, Folder One, Edgar Snow Papers, University of Missouri-Kansas City Archives.

[7] B. Winfield, Edgar Snow and the Foreign Correspondence[C]// Sun Hua, ed., Edgar Snow, Beijing: Peking University Press, 2011, pp.134-5.

[8] E. Snow, "The Davies Case: Mr. Snow Takes Exception to Dispatch Published in the Times." New York Times, Dec. 12, 1953.

[9] J. M. Hamilton, Edgar Snow: A Biography, translated by Ke Wei-min, Shenyang: Liaoning University Press, 1990, pp.231-248.

[10] D. MacArthur, "Censorship in Japan Denied by MacArthur." New York Times, April 8, 1948, p.12.

[11] W. Sullivan, "U.S. Purges Libraries It Runs in Germany." New York Times, June 11, 1953.

[12] M. Bracker, "Books of 40 Authors Banned by U.S. in Overseas Libraries." New York Times, June 22, 1953.

[13] E. Snow, "Snow Denies the Charge He Ever Was a Red." New York Times, Feb. 17, 1952.

[14] E. Snow, Red Star Over China, Beijing:Foreign Language Teaching and Research Press, 2005, pp.667-733.

[15] E. Snow, "Must China GO Red?" Saturday Evening Post, May 12, 1945, p.67. 